\title{
Impact of Liquidity Shortage Risk on Financial Performance of Sudanese Islamic Banks
}

\author{
Omer Allagabo Omer Mustafa \\ Sudan Academy for Banking \& Financial Sciences (SABFS-Sudan), Sudan \\ Corresponding email: omergabo78@sabfs.edu.sd,
}

\begin{abstract}
The paper aims to examine the impact of Liquidity Shortage Risk (LSR) on the financial performance of Islamic Commercial Banks (ICBs) in Sudan (1992-2018). The following explanatory powers were used to indicate LSR; which include: liquid assets to total assets, total finance to total deposits, current deposits to total deposits and inflation as a control factor. The financial performance of ICBs (the dependent variable) was measured by the return on assets. To concludes the relation between the variables, data were analyzed thought used Ordinary Least Squares technique. The main findings revealed that current deposits to total deposits, total finance to total deposits and inflation negatively affected the financial performance. While liquid assets to total assets have positive influence to the performance of ICBs. Monetary policy indirectly contributed to the exposure of ICBs to LSR through money supply increase. Moreover, high inflation motivated depositors to high cash withdrawal from their deposits; and, consequently exposed ICBs to LSR. The study recommends that ICBs should not wholly depend on current deposits as a source of finance, because customers' default might lead to LSR resulting in deteriorating profitability. Moreover, diversification of financial assets (with high liquidity) protects them from LSR. As for the central bank, the contractionary monetary policy is a crucial to control inflation in order to improve the financial performance of ICBs.
\end{abstract}

Keywords: Liquidity, Risk, Banks, Sudan

JEL Classification: E52; G21; G32; N27

@ IJIEF 2020 published by Universitas Muhammadiyah Yogyakarta, Indonesia All rights reserved

DOI:

https://doi.org/10.18196/ijief.3229
Web:

https://journal.umy.ac.id/index.php/ijief/article/view/8744

Citation:

Mustafa, O. A. O. (2020). Impact of liquidity shortage risk on financial performance of Sudanese Islamic banks. International Journal of Islamic Economics and Finance (IIIEF), 3(2), 251-282. DOI: https://doi.org/10.18196/ijief.3229 


\section{Introduction}

\subsection{Background}

Islamic commercial banks (ICBs) are financial institutions with main objective is to satisfy the instructions of the Holy Quran in all their financial transactions with totally avoiding interest rate (Mustafa,2019a, p.14). Liquidity is the ability of banks to cover/meet their financial obligations in its time. The Liquidity is important to sustainability of any financial institution specially banks. Thus, liquidity management is the one of the most important actions conducted by banks. Good liquidity management will lead to reduce the possibility of banks to face some problems (bankruptcies). Basel Committee on Banking Supervision (BCBS) ${ }^{1}$ has mentioned that, current technological and financial modernisations have provided banks with new methods to financing their operations and supervising their liquidity position. (BIS,2000, p.1). Meanwhile there is a correlation between banks' liquidity and their financial soundness, therefore, a careful management of liquidity ensures the stability of the banking system. Liquidity management for ICBs compared to the conventional banks - is differed because of the most existing instruments used for managing liquidity in conventional are interestbased, for that reason, managing liquidity in ICBs should complies with Shari'ah rule (Ariffin, 2012, p.77).

If a bank become unable to meet cash withdrawal of customers from their accounts this means that it has a problem in managing its liquidity (liquidity shortage), liquid assets to total assets ratio is use to measures the shortage of liquidity. But if a set of banks faced shortage of liquidity as happened in Sudan in 2018 this position influences their financial performance and might have linked to macro-policy (monetary policy, money supply, inflation, size of production and people behavior in the community). The problem of the research is derived form the question: if all ICBs in Sudan are exposed to liquidity Shortage Risk (LSR), what will be happen to their financial performance? Previously, significant studies have been runes regarding the proficiency of Islamic banking in general, but quantitative research is still needed to runes on the area of effect of LSR on the financial performance of Islamic Banks locally and regionally.

\footnotetext{
${ }^{1}$ The BCBS is a supervisory body which was founded in Switzerland in the year 1975 by the governors of the Central Banks of the G10 countries. It is involving experts' representatives of banking supervisory authorities and central banks from all over the $\mathrm{G} 10$ countries.
} 
Mustafa Impact of Liquidity Shortage Risk on Financial Performance of Sudanese Islamic Banks

This paper seeks to contribute to highlighting this issue through analysing and assessing the impact of LSR on the financial performance of Islamic banks in Sudan in (1992-2018) period.

\subsection{Objectives of the Research}

The study attempts to achieve the following objectives: 1) To examine the relationship between LSR and the financial performance of ICBs in Sudan (1992-2018); 2) To assess the efficiency of monetary policy in mitigating the ICBs exposure to LSR; and 3) To discuss the reasons which led to LSR that ICBs faced in Sudan in 2018.

Moreover, the study aims to examine the following hypotheses: 1) There is a significant relationship between LSR and the financial performance of ICBs; and 2) Monetary policy is effective in mitigating ICB's exposure to LSR.

The paper organized to contains an introduction includes background of the study and the objectives of the Research, followed by review the literature related to theories, methodologies and previous studies on liquidity shortage risk. After that the study shifted to describes the methodology of the research which contain the data employed, model description and the method used to estimate the model. Subsequently, the study analysed the results obtained from; data on Islamic Banking in Sudan and output of the estimated model. Finally, the paper discussed the conclusions and mentioned the recommendations.

\section{Literature Review}

\subsection{Theoretical Basis for Measuring LSR}

Conventionally, banks use quantitative approaches based on controlling instruments to analyse their liquidity position. Moreover, the bank's position associated with liquidity risk is newly evaluated through quantitative methods based on financial ratios. Measuring liquidity risk shortage(LSR) is challenging for Islamic banks for the difficulties of keeping, collecting, sorting, classifying and analysing of the financial data. Theoretically, the liquidity position of the bank is judged by computing some financial ratios, such as a dividing Current Assets (CA) by Current Liability (CL), CA by Total Assets(TA), Liquid Assets (LA) by Total Assets(TA), Current Deposits(CD) by Total Deposits(TD) and Total Finance (TF) by (TD). Generally, higher ratios indicating that, bank in its better position regarding to liquidity. But if a bank keeping higher liquidity ratios such procedure has a negative effect on a bank's profitability (Liquidity and Profitability Trade-Off). Another 
Mustafa Impact of Liquidity Shortage Risk on Financial Performance of Sudanese Islamic Banks

methodology to measure liquidity risk is to compute the maturity gaps. It gives the bank an indication for LSR (Rania,2013, pp.1924- 1934). Recently, some scholars such (Resti and Sironi, 2007), (Anolli and Resti, 2008), (Bessis, 2009), (Hull, 2012), and (Tutino, 2012) has developed three dissimilar methodologies for measuring LSR namely: Stock-based Approach(SA), Cash Flow -based Approach(CFA) and Hybrid Approach(HA). The three approaches (SA, CFA and HA) were based on that banks are exposure to funding liquidity risk. The funding liquidity risk clarifies the fact that a bank incapable to well cope with unanticipated cash leakages. It is the incapability of a bank to fulfil its own obligations on time. According to Scannella (2016, p.5), the funding liquidity risk includes; 1 ). Liquidity mismatching risk: the mismatch between amount and maturity of cash inflows and cash outflows. Moreover, gap between liquid asset and liability of bank causes liquidity shortage risk; 2.) Liquidity contingency risk: future actions may make the bank forced to search for extra liquid assets; 3). Margin call liquidity risk: greater margin calls on the derivatives rise the liquidity risk as cash outflows increase and; 4). Failure to meet daily payments and requirements of the collateral. The liquidity risk types are interrelated, leading banks to look for more funds to cover unexpected cash outflows or to liquidate some assets.

With (SA) approach, it is not difficult to calculate and monitor the liquidity risk. Through dividing assets and liabilities into cashable assets2 (marketable), instable liabilities3 and off-balance sheet obligations to finance, it is possible to evaluation the bank's ability to bear up liquidity shortages.

\section{Cash Position \\ = Marketable Assets - Instable Liabilities-Obligations to Finance (1)}

Equation (1) shows that, if the cash position of bank is greater than 0 indicates that, it has a positive margin of funds to cover changes in liabilities and commitments regards to finance. Moreover, it measures the stock of assets that can be liquidated on time to cope with banks' liquidity shocks.

On the other hand, the CFA implies two types of liquidity gaps: marginal liquidity gap and cumulative liquidity gap. The first gap measures the net unequilibria between cash inflows and cash outflows related to bank's operations while the second gap measures the cumulative liquidity gap as the sum of marginal liquidity gaps (Ibid, p.8). Additionally, the CFA is able to estimate the influence of liquidity variations using periodic gaps that are in

\footnotetext{
${ }^{2}$ Includes all assets in the balance sheet of bank that can rapidly transformed to cash.

${ }^{3}$ Includes wholesale financing and unpredictable changes of customer deposits.
} 
Mustafa Impact of Liquidity Shortage Risk on Financial Performance of Sudanese Islamic Banks

line with the nature of bank's assets and liabilities. The estimation of the different gaps of liquidity for different times improves ability of banks to tackle LSR. The two dissimilar approaches (SA and CFA) are complementary methods quantifying LSR in banking. The SA measures the exposure to liquidity risk in terms of cash shortages and long-term finance ratios. The CFA measures the exposure to liquidity risk in terms of liquidity gaps or LSR and expected cash flows, rise and fall of assets, liabilities and situations of offbalance sheet. The adjusted CFA is known as 'Hybrid Approach' (HA) adjusts the CFA taking into consideration the unrestricted assets that can be sold or guaranteed to get cash funds by collateralised loans or repurchase operations. But the problem with HA is that in Islamic banks it is not allowed to get cash with guaranteed loans, however, when the problem is solved the HA can be applied.

The development of models (SA, CFA and HA) makes it possible to attain greater truth in estimating the measures of liquidity shortage risk. Furthermore, CFA and HA are affected by some restrictions regarding the calculation of cash flows, division and sorting it into different scheduled time. The assumptions on allocation and estimation of cash required and cash outflows will affect liquidity gaps. The key simplifying assumptions required for any approach or methodologies are used to measures LSR should be includes at least one of: expected maturity between assets and liabilities; clients' behaviour and their response to changes in economic volatility; expected fluctuations regards sight deposits and demand accounts and options about assets and liabilities.

\subsection{Previous Studies}

In Islamic Banking the risk of withdrawal cash increases as they pay savers, investors, shareholders and depositors a share of the profit that is not prefixed. The rate of return on assets/equity and the implementation of profit and loss sharing (PLS) rule contributes uncertainty or unsure concerning to the actual value of the funds deposited. The ICBs may exposing to pressure of pay of returns like any other institutions (locally or regionally), as they sure that the depositors will make the bank bear the responsibility of the lower return which causing withdrawal of funds by the holders of deposit consequently LSR arises.

Most of past studies focused on the definition of the liquidity shortage risk (LSR) from the banks' aspect that the inconsistency in the ability of the lending system of banks to fund rises in assets and cover obligations in its relevant time when the payment become due (BCBS, 2008). This aspect is supported by the study of Greuning and Iqbal (2008). In addition to Mounira (2008) that LSR refers to failure of banks to meet their expected and 
Mustafa Impact of Liquidity Shortage Risk on Financial Performance of Sudanese Islamic Banks

unpredicted present and future cash flow needs and guarantee wants. This situation rises question of how Islamic banks behave when they are exposes to LSR? According to Diamond (2005), some financial crises happen at the time of banks fail to fulfil the demand for money (LSR) and the difficult arises when liquid assets totally fade within a short time as a result of increased deposit withdrawals. Subsequently, banks are involuntary sell specific assets in order to protection their obligations and avoid insolvency but if assets liquidated were inadequate, LSR will rises.

For the important of LSR in practice, many researches and formal regulatory bodies has stressed LSR management that, ICBs should take in their account, LSR management policy that covers a wide process for defining, determining, measuring and monitoring LSR (IFSB,2012). While Almani and Oehler (2012) disputed that Islamic Banks faces constraints in re-granting the finance because of the prohibition of interest. Islamic Banks normally keep a lesser levels of liquidity compared to conventional for the reasons include: a) absence or inactive of interbank money market; b) lack of a lender of last resort; and c) the focus on short term investments in their investment portfolios. Moreover, the application of (PLS) rule between the provider of finance (the bank) and the debtor client is matter to Sharia; so keeping adequate assets with high-quality to insurance liquidity needs is inappropriate in the system of Islamic finance because the mechanism of (PLS) contribute to the mitigate of the effect of general risks faced by Islamic banks (Jaara, Jaara, Shamieh and Fendi, 2017). The theoretical and monitoring framework for systemic liquidity risk as stated by European Central Bank (2018), stressed on the legal foundation for macro-prudential liquidity instruments under (Article 458 of the Capital Requirements Regulation, Articles 105 and 103 of the Capital Requirements Directive and national law), which is important condition for the application of macroprudential liquidity instruments in the European Union.

Empirical evidences on LSR management from the past studies like Hidayat (2012) shows that respondents such Bahraini Islamic Banks are unsurely about of the efficiency of LSR management. As for the relationship between bank's financial performance and LSR there is only statistical significance when the normality assumption was relaxed through the appropriate technique as examined by Berrios (2013). The results of Almumani (2013) presented that bad debt to equity, capital adequacy and return on assets had positive relations with LSR, while size of bank, total finance to total asset ratio, total finance to total deposit ratio and return on equity have inverse relationships with LSR whatever kind of bank (Islamic or conventional) but Cucinelli (2013) Sheds light on size of bank, capitalization, assets quality and specialization may can have effect on LRS management. This partially agreed 
Mustafa Impact of Liquidity Shortage Risk on Financial Performance of Sudanese Islamic Banks

with the results of Mustafa (2019a) that the risk indicators and inflation have a negative relationship with the financial performance (in terms of ROA) of Sudan's Islamic banks in (1995-2017) period. But it is different with the results of Mustafa (2019b), where it showed that liquid assets to total assets ratio have a positive relation with the provision of banking finance whereas return on assets is linked negatively with the finance.

On the other hand, some researches are tried to update the determinants of LSR by introduces macroeconomic variables to the analysis. According to Shen, Chen and Kao (2009) some economic factors affect LSR management in both Islamic banking and conventional where the system converts liabilities (deposits) into liquid rights or dues (granting finance, credit facilities or loans), this basic operation and through "money multiplier" make banks exposed to LSR risk. In the same direction, Moussa (2015) found that GDP growth, inflation rate, Capital, loans to total assets and operating costs to total assets have a significant influence on bank's liquidity in Tunisia. While the study of Mazur and Szajt (2015) concentrated partially on microeconomic factors such credit risk, effectiveness level, size of the bank, financial leverage level and engagement in the interbank market as internal factors of LSR. Furthermore, Yaacob (2016) introduced two new factors as suggested by BCBS includes liquidity coverage ratio and net stable funding ratio. The results shown that capital adequacy and financing are probable have influence on LSR management in the short term. Moreover, macroeconomic indicators (GDP and inflation) displayed a significant relationship with LSR on the long term. Mustafa (2020) used economic and financial data to test why Islamic banks focused on Murabaha mode and its effect on banking risk and performance. The basic result that banks with used the Murabaha succeed to increased their profit but exposed to more risk.

The discussion of the previous studies pointed out that, there is a variation in the results and effects related to liquidity shortage risk because of banks are differ in applied of some criteria including; the methodology used to define the liquidity risks, how to measure them, banking environment and philosophy (whether Islamic or conventional), difference in economic variables which used to measure the impact on the banks' performance. However, Islamic Banking is still need to studying the issue of LSR in order to build adequate and strong literature help Islamic banks practically in managing LSR compared to the literature of conventional banking. This study basically wishes to inspect the LSR' impact on the banks' performance in Sudan. 
Mustafa Impact of Liquidity Shortage Risk on Financial Performance of Sudanese Islamic Banks

\section{Methodology}

\subsection{Data}

The study uses annually secondary data (1992-2018). Data were obtained from the published reports of the Sudan's monetary authority. In addition to the previous studies in relation to LSR. The selected period includes important economic actions; in 1992 some ICBs in Sudan were merged in accordance with the economic liberalization policies to meet international solvency standards. Moreover, South Sudan seceded in the year 2011 and is considered the one the reasons behind exposure ICBs to LSR specially in 2018. The study applied the Ordinary Least Squares process to concludes how the LSR influence the financial performance of ICBs in Sudan.

\subsection{Model Development}

The following model is designed to answer the question of how liquidity shortage risk (LSR) will be affect the financial performance (FP) of Islamic commercial banks (ICBs).

$$
(F P) \text { of (ICBs) f (Liquidity Shortage Risk Indicators, Control Factors) }
$$

"Eq. (2)" implies that the financial performance of banks (the dependent variable) is a function in the indicators of liquidity shortage risk and inflation (the independents variables).

Rewritten "Eq. (2)" we have:

$$
(F P) \text { of }(I C B S)=f(\text { LSR, Control Factor })
$$

"Eq. (3)" indicates that when LSR take place may lead to inadequacy funds because the bank will look for other sources of finance to cover up the loss. It will also lead to reduce liquidity required to meet up with other customer's demand and thus less profitability or even bankruptcy. This shows that LSR and returns are interrelated that, higher liquidity shortage lead to fewer returns (Sinkey, 1992, p.47). Banks act as a link between all economic sectors through providing needed funds for these sectors. The inflation variable was introduced to the model as a control factor reflecting the efficiency of the monetary policy in maintaining economic stability. High inflation causes 
Mustafa Impact of Liquidity Shortage Risk on Financial Performance of Sudanese Islamic Banks

deterioration value of money thereby reduces the real profitability 4 of the banks (Marianne, 2001,28).

"Eq. (3)" can be rewritten as follows:

$$
R O A=f\left(\left(\frac{L A}{T A}\right),\left(\frac{C D}{T D}\right),\left(\frac{T F}{T D}\right),(I N F)\right)
$$

Where:

ROA is Return on Assets. It is commonly defined as net income earned (or pre-tax profit)/total assets. It provides information about management's performance in using the assets of the business to generate income (Adam,2014, p165).

(LA/TA, CD/TD, TF/TD, INF) are Indicators of LSR.

( $L A / T A)$ is the ratio of liquid assets to total assets. This ratio indicates LSR; the decrease of liquid assets to total assets ratio may expose the ICBs to LSR because in case of the decrease of liquid assets makes ICBs unable to fulfil withdrawal from banks' accounts. Hence, it is negatively related to the performance of ICBs.

( $C D / T D)$ is the ratio of current deposits to total deposits. An increase in the current deposits will improve the liquidity of ICBs, consequently the financial performance.

(TF/TD) is the ratio of total finance to total deposits. It indicates to both LSR and credit risks, an increase in provision of finance to total deposit may expose the ICBs to credit risk because in cases inability of customer to pay back. Hence, it is negatively related to the profitability of the bank (IFSB, 2013). There another interpretation will be; the provision of finance is one of the main sources of bank profitability. Therefore, if a bank relies on granting finance on current deposits, it increases its profitability and thus improves performance, but may lead to the possibility of exposure to LSR, therefore, the relationship between the granting of finance and profitability is positive (Mekasha, 2011, p.73).

INF is the inflation rate; Inflation indicate an external environment that might influences the bank's performance. It is directed ICBs to choice of granting or not granting the financing. The sign for the relationship between inflation

\footnotetext{
${ }^{4}$ In banking industry, the term profitability measures the capability of banks to create the profits.
} 
and the performance is expected to be a negative due to the deteriorated value of money (Mustafa,2019a, p23).

"Eq. (4)" is specified in symbols as follows:

$$
R O A=\beta 0+\beta 1\left(\frac{L A}{T A}\right)+\beta 2\left(\frac{C D}{T D}\right)+\beta 3\left(\frac{T F}{T D}\right)+\beta 4(I N F)+\mu i
$$

(5)

Where:

$\beta 0=$ The intercept.

$\beta 1, \beta 2, \ldots, \beta 4=$ The betas $(\beta s)$ are the parameters that OLS estimates. $\mu \mathrm{i}=$ Error term.

\subsection{Method}

There are a various types of regression methodologies can be used in scientific research. One of the most important estimation methods, namely, the method of Ordinary Least Squares(OLS). OLS is a statistical technique that is capable of determining the line of best fit of a model and seeks to find the minimum sum of the squares of residuals. This method is extensively used in regression analysis and estimation (Peprah and Mensah, 2017, p. 78). Furthermore, it enables researchers to examine relationships between variables in the linear regression model (LRM). LRM is a modeling technique where a dependent variable is predicted based on one or more independent variables. Moreover, it is allowing to investigate the specific effects variables have on one another. (Kumari and Yadav, 2018). Fox (2016) described that, OLS regression method is assumed to have a linear trend during estimating the unknown parameters of LRM, so, the OLS estimates are determined as the regression coefficients that minimize the sum of squared differences between the outcome variable and the linear combination of explanatory variables. According to Mahaboob, Venkateswarlu, Narayana, Ravi and Balasiddamuni $(2018$, p.518) if the regression model involves more than two regressor variables, it is called a "Multiple Linear Regression Model (MLRM)" specified as follows:

$$
Y_{i}=\beta_{0}+\beta_{1} X_{1 i}+\beta_{2} X_{2 i}+\cdots+\beta_{k} X_{k i}+e_{i}, i=1,2 \ldots n
$$

Where $\beta_{0}$ is the intercept and the parameters $\beta_{1,2 \ldots k}$ are known as regression coefficients. Usually $Y_{i}$ is called the dependent variable and $X_{k i}$ are called the independent variables or the explanatory variables. If the MLRM fulfill the linearity assumption, OLS is the best method to estimate of relationship between $Y_{i}$ and $X_{k i}$ because it minimizes the sum of squared vertical distances between the observed dataset and the responses forecasted by the linear approximation. 
Mustafa Impact of Liquidity Shortage Risk on Financial Performance of Sudanese Islamic Banks

Economists such (Mosteller, Frederick and Tukey,1977, P.48) have traditionally referred to Equation (6) as ordinary least squares or (OLS), putting this equation in matrix terms, we have:

$$
\left[\begin{array}{c}
\mathrm{y}_{1} \\
\mathrm{y}_{2} \\
\ldots \\
\mathrm{y}_{\mathrm{n}}
\end{array}\right]=\left[\begin{array}{cccc}
1 & \mathrm{x}_{11} & \ldots & \mathrm{x}_{1 \mathrm{k} *} \\
1 & \mathrm{x}_{21} & \ldots & \mathrm{x}_{2 \mathrm{k} *} \\
\ldots & \ldots & \ldots & \ldots \\
1 & \mathrm{x}_{\mathrm{n} 1} & \ldots & \mathrm{x}_{\mathrm{nk} *}
\end{array}\right]\left[\begin{array}{c}
\beta_{0} \\
\beta_{1} \\
\ldots \\
\beta_{\mathrm{k} *}
\end{array}\right]+\left[\begin{array}{c}
e_{1} \\
e_{2} \\
\ldots \\
e_{\mathrm{n}}
\end{array}\right]
$$

Output of "Eq. (7)" is

$$
\mathbf{y}=\mathbf{X} \boldsymbol{\beta}+\boldsymbol{e}
$$

The number of columns of the $\mathbf{X}$ matrix is $k=k^{*}+1$. X containing $k^{*}$ "real" independent variables, plus there is one additional independent variable that is nothing more than a series of 1 's.

The tool of prediction is a linear combination of independent variable values, with coefficients known as $\beta^{\prime}$ s. The prediction for $y_{i}$, in other words $\mathrm{E}\left(\mathrm{y}_{i}\right)$, is traditionally notated with a hat as below:

$$
\widehat{\boldsymbol{y}}=\mathbf{X} \boldsymbol{\beta}
$$

The difference between $\hat{\mathrm{y}}$ and $\mathrm{y}$ is the error, that is $\mathrm{e}=\mathrm{y}-\hat{\mathrm{y}}$ as $\mathrm{y}=\hat{\mathrm{y}}+e$ The error vector is a key input in ordinary least squares. Assumptions about the nature of the error are largely responsible for our ability to make inferences from and about the model that $E(e)=0$ where both e and 0 are $n$ by 1 column. Note that this is an assumption that does not restrict us in any way. If $E(e) \neq 0$, the difference would simply be absorbed in the $y$-intercept, $\beta_{0}$.

In this study, the OLS technique was used to estimate the model which described in equation (5). The reason behind choosing OLS, that the model is based on assumptions that there is a linearity relationship between a response variable (ROA or the bank's performance) and predictor variables (LSR and Inflation), moreover, there is no autocorrelation among a set of variables. The Durbin-Watson (DW) statistic is a good test for this assumption. Therefore, OLS enables to determine the variables' trend (positive or negative) and measure the power of the relationship between ROA and set of independent variables. Moreover, the analysis of the financial indicators of ICBs in Sudan and model output (Adjusted R-squared, F-statistic, probability of (F-statistic), DW statistic, coefficient value and variables probability) help us to understand how (ROA) is response to changes in the values of (LSR and Inflation). 


\section{Results and Analysis}

\subsection{Islamic Banking in Sudan}

Bank's performance involves two aspects of solvency and sustainable profitability. As (solvency-improving) measures primarily affect bank's balance sheets while (profitability-improving) measures affect bank's income. Financial performance is the monetary term for measuring firm's operations, policies, assess financial conditions, income statements and the balance sheets of companies (Adam, 2014, p.164).

Since 1992, CBOS adopted a number of regulative measures to comply with BCBS accords which emphasized on LSR, exchange rate fluctuations and inflation. Moreover, implementation of supervisory policies aimed at achieving the financial stability of ICBs that ensures the efficiency of the banking system.

Table 1. Financial Indicators of Sudan's ICBs (1992-2018) Percentage\%

\begin{tabular}{|c|c|c|c|c|c|}
\hline Year & $\begin{array}{c}\text { Capital } \\
\text { Adequacy } \\
\text { Ratio (CAR) }\end{array}$ & $\begin{array}{l}\text { Non-Performing } \\
\text { Loans to Total } \\
\text { Funding (NPL/TF) }\end{array}$ & $\begin{array}{c}\text { Financing Provision } \\
\text { to Non-Performing } \\
\text { Loans (FP/NPL) }\end{array}$ & $\begin{array}{c}\text { Return on } \\
\text { Assets } \\
\text { (ROA) }\end{array}$ & $\begin{array}{c}\text { Liquid Assets } \\
\text { to Total Assets } \\
\text { (LA/TA) }\end{array}$ \\
\hline 1992 & 3.4 & 6.1 & 9.4 & 1.3 & 17 \\
\hline 1993 & 3.7 & 7.5 & 10.1 & 1.1 & 19.5 \\
\hline 1994 & 3.9 & 9.0 & 8.9 & 1.4 & 22.6 \\
\hline 1995 & 4.0 & 11 & 7.4 & 0.9 & 19 \\
\hline 1996 & 5.6 & 13 & 10 & 0.6 & 21 \\
\hline 1997 & 7.2 & 15.1 & 8.1 & 3.3 & 29 \\
\hline 1998 & 9.0 & 15.6 & 9.0 & 1.0 & 26 \\
\hline 1999 & 6.0 & 23 & 8.9 & 1.2 & 10 \\
\hline 2000 & 7.0 & 16 & 28.4 & 3.0 & 7.0 \\
\hline 2001 & 11 & 17 & 23.2 & 0.9 & 20.9 \\
\hline 2002 & 9.0 & 13 & 37.5 & 4.0 & 18.6 \\
\hline 2003 & 10 & 11 & 44.2 & 5.0 & 19.2 \\
\hline 2004 & 12 & 9.0 & 33.7 & 5.3 & 18.3 \\
\hline 2005 & 19 & 7.0 & 19 & 5.0 & 17.4 \\
\hline 2006 & 27 & 19 & 3.2 & 2.1 & 17.0 \\
\hline 2007 & 25 & 17 & 24 & 2.5 & 21.0 \\
\hline 2008 & 12 & 15 & 27 & 3.0 & 20.9 \\
\hline 2009 & 11 & 15.1 & 29 & 3.4 & 27.6 \\
\hline 2010 & 10 & 14.1 & 31.1 & 3.9 & 22.5 \\
\hline 2011 & 13 & 12.6 & 39.7 & 4.20 & 32.0 \\
\hline 2012 & 12 & 11.9 & 36.4 & 4.40 & 41.5 \\
\hline 2013 & 16.6 & 8.40 & 37.0 & 3.70 & 39.0 \\
\hline 2014 & 18.0 & 7.10 & 61.7 & 4.00 & 39.1 \\
\hline 2015 & 20.2 & 5.10 & 90.7 & 4.00 & 37.4 \\
\hline 2016 & 18.7 & 5.20 & 60.0 & 4.70 & 35.1 \\
\hline 2017 & 16.2 & 3.30 & 81.3 & 3.80 & 37.3 \\
\hline 2018 & 9.9 & 3.20 & 72.0 & 4.70 & 52.0 \\
\hline
\end{tabular}


Mustafa Impact of Liquidity Shortage Risk on Financial Performance of Sudanese Islamic Banks

Source: CBOS, Annual Reports, (1992-2018)

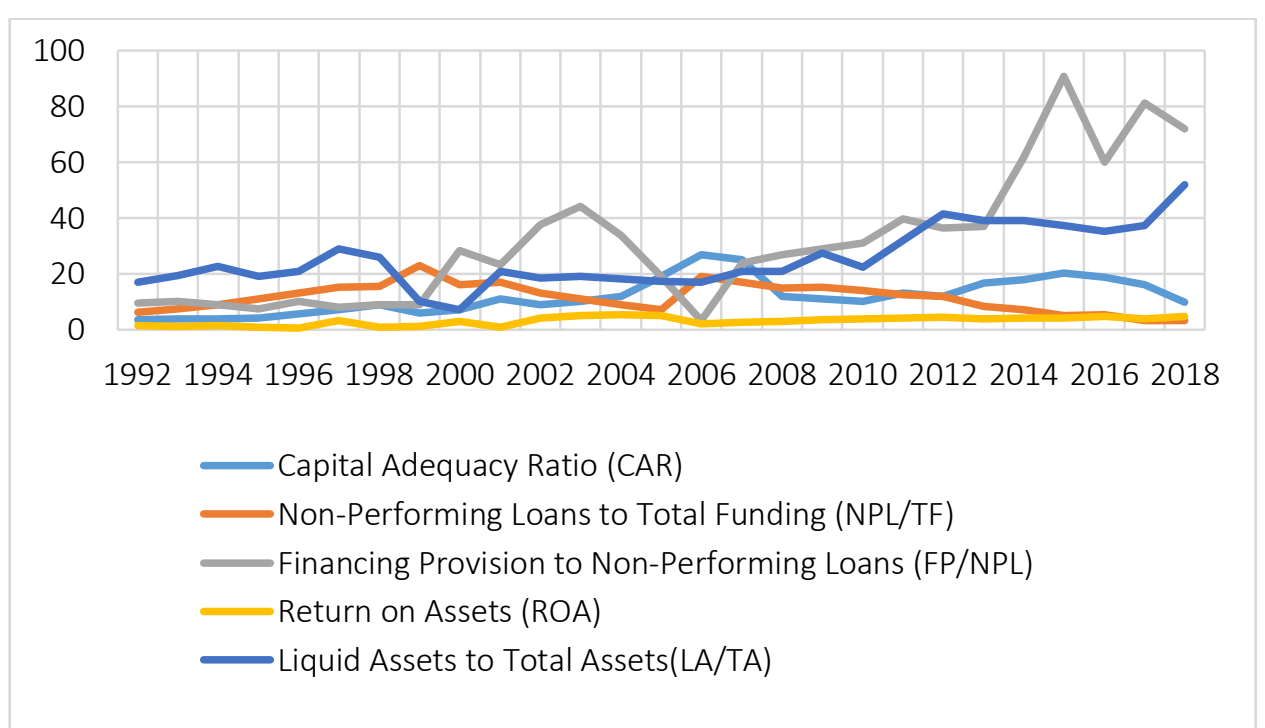

Figure 1. Trend of Financial Indicators of ICBs in Sudan 1992-2018 Sources: CBOS, Annual Reports (1992-2018)

In light of table1 and figure1, since 1992 up to 2003, capital adequacy ratio ${ }^{5}$ ranged between (3\%-10\%) remained below its standard level. But during (2004-2017) except (2009-2010), it was fluctuating within its standardized ratio (12\%-20\%).Moreover, it sharply declined to $9.9 \%$ in 2018 for a growing of risky assets because of Sudan's local currency devaluated indicating inefficiency of Banks's regulatory capital to deal with banking risk.

During 1992-2014, non-performing loans to total financing ratio ${ }^{6}$ (NPL/TF) ranged between (6\%-19\%) representing inefficient utilization of fund. But it decreased notably from $5.1 \%$ in 2015 to $3.2 \% 2018$ reflecting the supervisory efforts of the CBOS to reach zero percentage.

For the duration of 1992-2018, the financing provisions to non-performing loans ratio ( $F P / N P L)$ ranged between $(3 \%-81 \%)$ indicating the reduction in the adequacy of provisions or in other word, ability of ICBs to deal with the credit risk declined.

For the period 1992-2018, the return on assets (ROA) ranged between (0.6\%$5.3 \%)$ indicating a weak financial performance and ICBs have no ability to invest their capital efficiently.

\footnotetext{
${ }^{5}$ Standardized Ratio and minimum required of CAR is $12 \%$.

${ }^{6}$ This ratio used to measure the quality of utilization of assets and the Standardized Ratio should not be more than $6 \%$.
} 
Mustafa Impact of Liquidity Shortage Risk on Financial Performance of Sudanese Islamic Banks

From the time when 1992 to 2010, liquid assets to total assets ratio7(LA/TA) ranged between $(7 \%-26 \%)$ indicating that it was out of its Standard Ratio (30\%-40\%). But it approximately reached its Standardized level (32\%-41\%) all through (2011-2017).

Although (LA/TA) reached $52 \%$ in 2018, ICBs in Sudan faced severe shortage of liquidity and they were unable to meet customers 'cash withdrawal from their accounts. This means that if banks owned highly liquid assets but they fail to liquidate them (the difficulty of converting to cash) they may also be exposure to LSR, which might negatively affect their financial performance.

\subsubsection{Balance Sheet Indicators of Islamic Commercial Banks in Sudan (1992-2018)}

The benefit of analyzing of balance sheet Indicators of banks is that such liquidity shortage risk results from the gap between the two sides of the balance sheet (assets and liabilities) in terms of maturities, generating either excess of cash that needs to be invested or a shortage of cash that needs to be funded (Mounira,2008, p.86). The best indicators used to assess the performance of the bank's consolidated balance sheet include: ratio of capital and reserves to total liabilities and the ratio of total finance to total deposits. Moreover, the comparison between the two ratios (total finance to total assets) and (total deposits to total liabilities) gives an indication of liquidity shortage risk (Mustafa, 2019a, p.28). duties.

\footnotetext{
${ }^{7}$ Standardized Ratio between (30\%-40\%) and it used to measure ability of banks to meet their cash duties in light of availability of liquid assets.
} 
Mustafa Impact of Liquidity Shortage Risk on Financial Performance of Sudanese Islamic Banks

Table 2. Banks's Balance Sheet Indicators

\begin{tabular}{ccccc}
\hline Year & (C\&R/TL)\% & (TF/TA)\% & (TF/TD)\% & (TD/TL)\% \\
\hline 1992 & 9.30 & 22.7 & 35.1 & 64.4 \\
1993 & 3.90 & 12.7 & 31.5 & 40.2 \\
1994 & 6.70 & 17.5 & 42.9 & 40.7 \\
1995 & 5.00 & 14.0 & 35.0 & 40.0 \\
1996 & 7.00 & 21.0 & 50.0 & 37.0 \\
1997 & 6.00 & 18.0 & 43.0 & 41.0 \\
1998 & 6.00 & 14.0 & 39.0 & 37.0 \\
1999 & 5.70 & 11.0 & 32.8 & 35.0 \\
2000 & 9.00 & 22.0 & 40.2 & 55.0 \\
2001 & 10.5 & 24.5 & 40.6 & 60.2 \\
2002 & 12.1 & 31.6 & 18.6 & 59.4 \\
2003 & 14.0 & 37.3 & 62.3 & 59.9 \\
2004 & 13.7 & 41.8 & 67.4 & 61.9 \\
2005 & 12.0 & 45.7 & 71.6 & 63.8 \\
2006 & 16.8 & 48.1 & 90.5 & 53.2 \\
2007 & 17.6 & 49.6 & 93.2 & 53.2 \\
2008 & 17.1 & 48.8 & 90.6 & 53.9 \\
2009 & 18.2 & 49.5 & 87.1 & 60.0 \\
2010 & 17.3 & 47.8 & 79.6 & 59.7 \\
2011 & 19.4 & 49.2 & 82.3 & 59.7 \\
2012 & 16.2 & 45.5 & 76.4 & 59.3 \\
2013 & 17.0 & 48.6 & 84.5 & 57.5 \\
2014 & 16.0 & 48.0 & 82.9 & 57.9 \\
2015 & 14.9 & 49.1 & 84.3 & 58.2 \\
2016 & 13.9 & 51.0 & 85.2 & 59.9 \\
2017 & 10.8 & 48.7 & 73.5 & 66.3 \\
2018 & 6.90 & 37.4 & 54.8 & 68.4 \\
\hline & $50 u r c e s: C B O S, A n n u a 1 R e p+5$ & $(1992-2018)$ \\
\end{tabular}

Sources: CBOS, Annual Reports, (1992-2018).

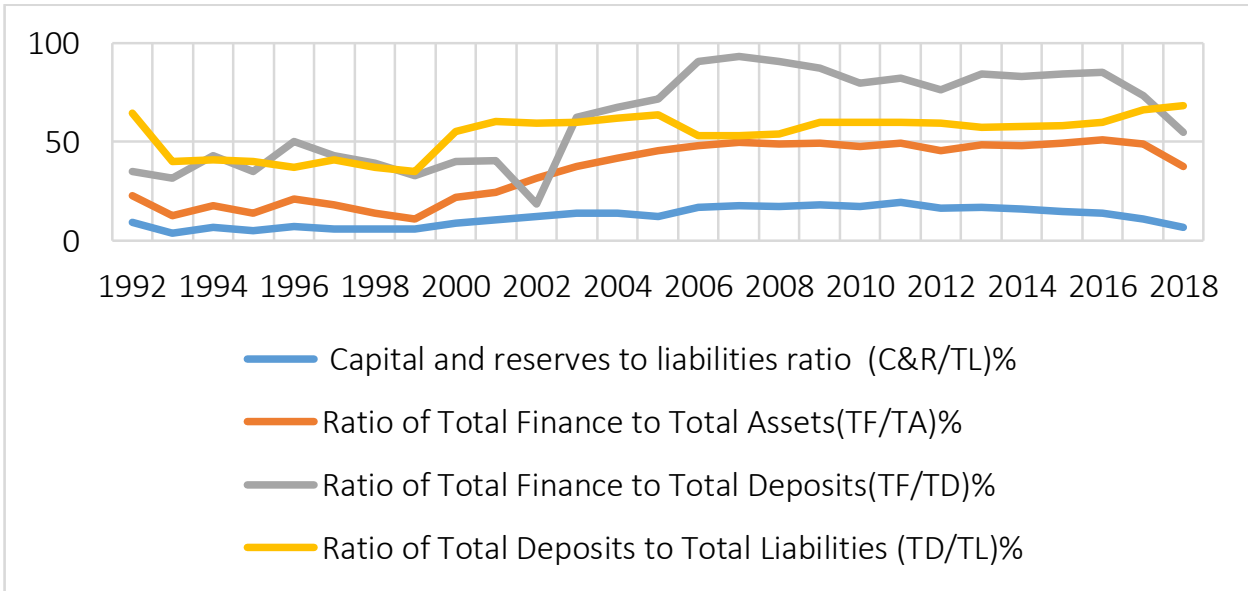

Figure 2. Trend of Balance Sheet Indicators of ICBs 1992-2018 Sources: CBOS, Annual Reports, (1992-2018). 
Mustafa Impact of Liquidity Shortage Risk on Financial Performance of Sudanese Islamic Banks

Table 2 and Figure 2 shows that, capital and reserves to liabilities ratio during the period (1992-2018) ranged between (3.9\%-19.4\%). It is note that Since 2011, it started to decline at a decreasing rate, reaching 6.9\% in 2018 due to the devaluation of the local currency for the reason of South Sudan secession.

Throughout 1992-2018, ratio of total finance to total deposits ranged between (18.6\%-9.32\%) and it declined from 73.5\% in 2017 to 54.8\% in 2018 due to increase of foreign deposits by $367.1 \%$ (CBOS,2018, p.82). In general, the reduction of this ratio it's a good indication because if a bank relies on deposits to the provision of finance might increase its profitability but may expose the bank to LSR.

During 1992-2004, total finance to total assets ratio ranged between (11\%$41.8 \%$ ) and it is note that total finance of ICBs is approximately equivalent to $50 \%$ of total assets during 2005-2017 and once again it declined to $37.4 \%$ in 2018 due to increase of foreign assets and deposits of ICBs with the CBOS by $309.7 \%$ and $363.4 \%$ respectively (CBOS, 2018, p.82).

During 1990s, total deposits to liabilities ratio ranged between (35\%-40\%) but it rapidly increased to range between (53\%-68\%) during the period (2000-2018) indicating clearly that ICBs in Sudan highly depends on their depositors' funds. This is possibly one of the reasons that led to the liquidity shortage crisis in 2018.

\subsubsection{Position of Banking Deposits 1992-2018}

ICBS in Sudan deal with three major customers including: Federal and state government, public enterprises and private sector. The following table describes the types of weighted accepted deposits during 1992-2018. 
Mustafa Impact of Liquidity Shortage Risk on Financial Performance of Sudanese Islamic Banks

Table 3. Progress of Banking Deposits (1992-2018)

Percentage\%

\begin{tabular}{|c|c|c|c|c|c|c|c|c|}
\hline \multirow{2}{*}{ Year } & \multicolumn{2}{|c|}{ Federal Government } & \multicolumn{2}{|c|}{ Public Enterprises } & \multicolumn{2}{|c|}{ Private Sector } & \multicolumn{2}{|c|}{ Total Deposits } \\
\hline & $\begin{array}{l}\text { Current } \\
\text { Deposits }\end{array}$ & $\begin{array}{l}\text { Savings \& } \\
\text { Investment } \\
\text { Deposits }\end{array}$ & $\begin{array}{c}\text { Current } \\
\text { Deposits }\end{array}$ & $\begin{array}{l}\text { Savings \& } \\
\text { Investment } \\
\text { Deposits }\end{array}$ & $\begin{array}{l}\text { Current } \\
\text { Deposits }\end{array}$ & $\begin{array}{l}\text { Savings \& } \\
\text { Investment } \\
\text { Deposits }\end{array}$ & $\begin{array}{l}\text { Current } \\
\text { Deposits }\end{array}$ & $\begin{array}{c}\text { Savings, } \\
\text { Investment } \\
\text { Deposits }\end{array}$ \\
\hline 1992 & 4.1 & 0.65 & 0.58 & 2.4 & 95.3 & 96.9 & 53.6 & 46.4 \\
\hline 1993 & 5.5 & 2.8 & 3.8 & 7.9 & 90.6 & 89.4 & 38.3 & 61.6 \\
\hline 1994 & 4.9 & 0.43 & 3.3 & 17.7 & 91.7 & 70.2 & 42.1 & 65.7 \\
\hline 1995 & 2.8 & 0.86 & 9.5 & 17.3 & 87.7 & 81.9 & 70.4 & 29.6 \\
\hline 1996 & 6.2 & 1.1 & 5.0 & 9.1 & 88.8 & 89.9 & 75.9 & 24.1 \\
\hline 1997 & 1.7 & 0.5 & 1.3 & 6.6 & 96.9 & 92.9 & 66.4 & 32.1 \\
\hline 1998 & 1.4 & 2.2 & 1.9 & 2.5 & 96.3 & 98.9 & 69.6 & 30.9 \\
\hline 1999 & 1.7 & 2.0 & 2.1 & 2.6 & 94.1 & 96.1 & 55.2 & 44.8 \\
\hline 2000 & 3.4 & 2.4 & 3.2 & 2.4 & 93.6 & 95.4 & 43.7 & 56.3 \\
\hline 2001 & 4.1 & 2.1 & 4.0 & 2.7 & 91.4 & 95.2 & 41.2 & 58.8 \\
\hline 2002 & 2.6 & 0.1 & 1.2 & 5.9 & 96.3 & 94.1 & 35.6 & 64.4 \\
\hline 2003 & 6.6 & 0.1 & 2.3 & 7.9 & 91.2 & 91.9 & 31.6 & 68.4 \\
\hline 2004 & 8.6 & 0.9 & 3.4 & 8.5 & 87.9 & 94.7 & 36.1 & 63.9 \\
\hline 2005 & 22.1 & 1.1 & 2.3 & 6.8 & 75.6 & 92.1 & 41.4 & 58.6 \\
\hline 2006 & 6.4 & 0.6 & 0.8 & 18.3 & 92.8 & 81.0 & 49.5 & 50.5 \\
\hline 2007 & 4.0 & 0.2 & 1.4 & 17.4 & 94.9 & 82.5 & 97.8 & 50.5 \\
\hline 2008 & 5.9 & 6.5 & 4.6 & 1.6 & 89.5 & 91.9 & 50.4 & 49.6 \\
\hline 2009 & 6.2 & 3.2 & 6.1 & 7.8 & 87.7 & 89.0 & 47.1 & 52.9 \\
\hline 2010 & 7.2 & 3.7 & 6.0 & 6.8 & 86.1 & 89.5 & 46.8 & 53.2 \\
\hline 2011 & 3.1 & 1.3 & 6.2 & 7.2 & 90.7 & 91.5 & 50.4 & 49.6 \\
\hline 2012 & 3.3 & 3.2 & 3.7 & 5.3 & 93.0 & 91.5 & 49.5 & 50.5 \\
\hline 2013 & 3.2 & 3.6 & 4.1 & 4.3 & 92.7 & 92.2 & 50.1 & 49.9 \\
\hline 2014 & 3.1 & 2.8 & 3.4 & 4.0 & 93.4 & 93.2 & 48.9 & 51.1 \\
\hline 2015 & 3.9 & 2.5 & 3.6 & 3.3 & 92.5 & 94.1 & 49.1 & 50.9 \\
\hline 2016 & 4.2 & 2.5 & 4.3 & 2.6 & 91.5 & 94.9 & 49.8 & 50.2 \\
\hline 2017 & 4.1 & 1.7 & 4.6 & 3.3 & 91.3 & 95.0 & 50.1 & 49.9 \\
\hline 2018 & 3.3 & 1.3 & 4.6 & 1.9 & 92.1 & 96.7 & 58.9 & 41.1 \\
\hline
\end{tabular}

Source: Author's Calculation 


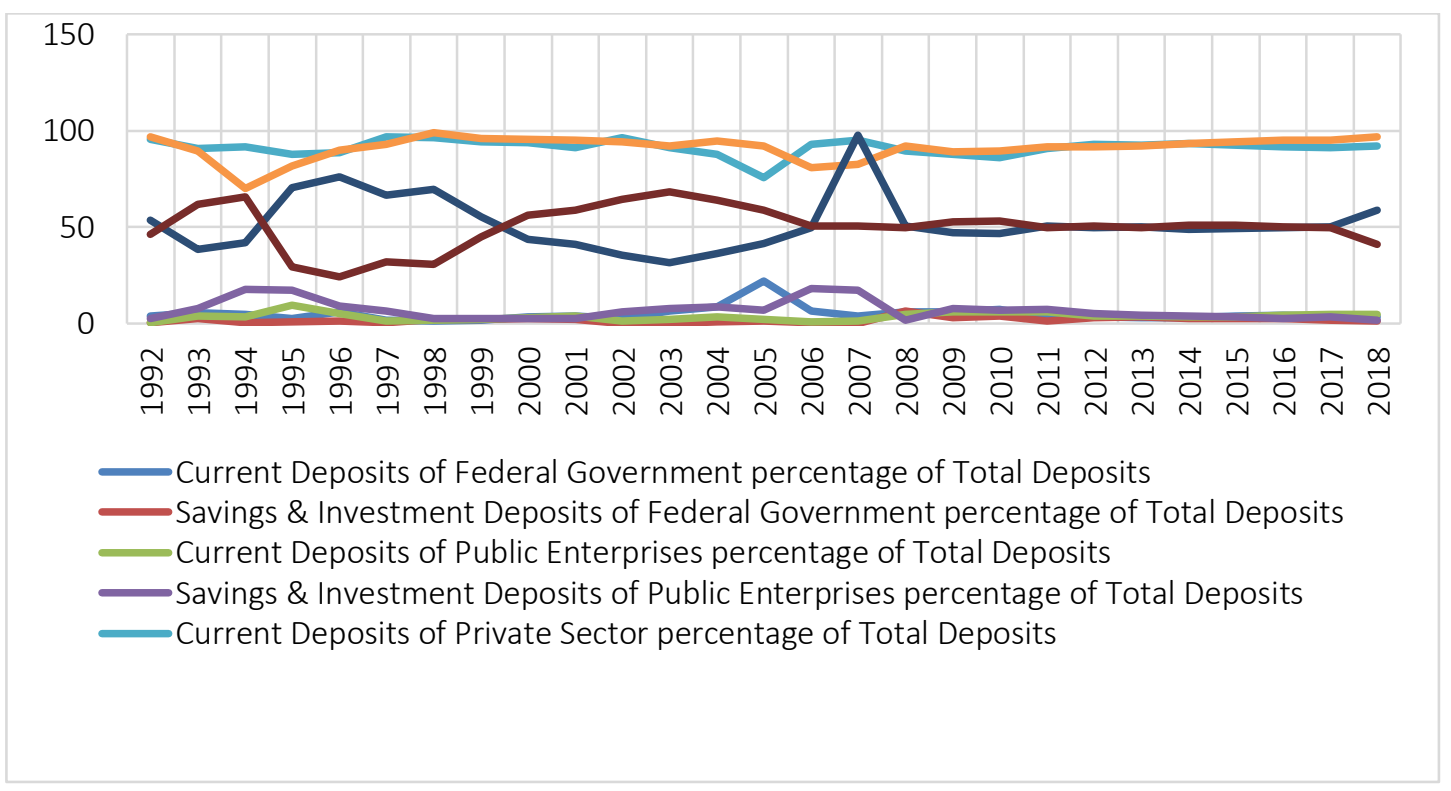

Figure 3. Trend of Banking Deposits 1992-2018

Source: Author's Calculation

As seen in table 3 and figure3, total current deposits of ICBs ranged between (31.6\%-97.8\%) of the total banking deposits, whereas savings and investment accounts ranged (24.1\%-68.4\%).

Current, savings and investment deposits of private sector represented about (70.2\%-96.7\%) of the total banking deposits indicating the heavy reliance of ICBs activities on the private sector transactions.

Current, savings and investment deposits of public enterprises showed about (0.58\%-18.3\%) of the total banking deposits.

Current, savings and investment deposits of federal and state governments demonstrated about $(0.1 \%-22 \%)$ of the total banking deposits.

In general, there is a decrease in deposits of state governments and public enterprises compared to an increase of private sector's deposits as a result of the implementation of the privatization and economic liberalization policy since the beginning of 1992.

\subsubsection{Key Indicators of Monetary Policy 1992-2018}

The best way to assess the efficiency of monetary policy is to analyze the components of money supply (MS) and inflation rate. Economically, there are three reasons that call on the Central Bank to print the currency or increase supply of money, which are a). printing to replace the damaged currency, b). printing and c). issuing currency to meet the GDP growth and printing to finance the deficit of the public budget of the state. The latest procedure resulted in inflationary effects on the economic (Khartoum Electronic Media Centre, 2018). 
Mustafa Impact of Liquidity Shortage Risk on Financial Performance of Sudanese Islamic Banks

Table 4. Key Monetary Policy Indicators (1992-2018)

Percentage\%

\begin{tabular}{ccccc}
\hline Year & (M2/GDP)\% & Inflation\% & $\begin{array}{c}\text { (Currency with } \\
\text { Banks/M2)\% }\end{array}$ & $\begin{array}{c}\text { (Currency with } \\
\text { Public/ M2)\% }\end{array}$ \\
\hline 1992 & 35.2 & 107.5 & 37.4 & 30.7 \\
1993 & 31.3 & 115.9 & 24.5 & 35.2 \\
1994 & 23.2 & 104.9 & 24.5 & 36.4 \\
1995 & 17.1 & 116.1 & 23.8 & 35.2 \\
1996 & 11.4 & 81.3 & 24.2 & 66.3 \\
1997 & 10.1 & 117.3 & 27.1 & 36.6 \\
1998 & 10.3 & 65.4 & 23.5 & 39.7 \\
1999 & 10.5 & 29.7 & 25.2 & 40.1 \\
2000 & 10.03 & 19.6 & 26.7 & 40.9 \\
2001 & 10.3 & 11.03 & 27.2 & 35.6 \\
2002 & 11.8 & 6.6 & 28.2 & 34.4 \\
2003 & 13.2 & 6.9 & 29.7 & 32.7 \\
2004 & 13.9 & 7.8 & 31.2 & 31.7 \\
2005 & 16.9 & 8.5 & 31.7 & 26.7 \\
2006 & 18.5 & 8.4 & 28.9 & 29.9 \\
2007 & 18.5 & 7.5 & 29.1 & 28.6 \\
2008 & 18.4 & 12.0 & 29.9 & 29.6 \\
2009 & 20.9 & 14.0 & 28.4 & 28.5 \\
2010 & 21.9 & 13.0 & 27.2 & 28.4 \\
2011 & 29.9 & 18.1 & 28.7 & 30.7 \\
2012 & 26.4 & 17.0 & 24.3 & 28.6 \\
2013 & 21.8 & 22.9 & 24.8 & 30.9 \\
2014 & 17.4 & 25.7 & 25.4 & 30.4 \\
2015 & 16.1 & 12.6 & 27.1 & 26.2 \\
2016 & 17.4 & 30.6 & 27.7 & 29.3 \\
2017 & 24.6 & 55.6 & 29.8 & \\
2018 & 35.1 & 72.9 & & 2.9 \\
\hline
\end{tabular}

Source: CBOS, Annual Reports, (1992-2018).

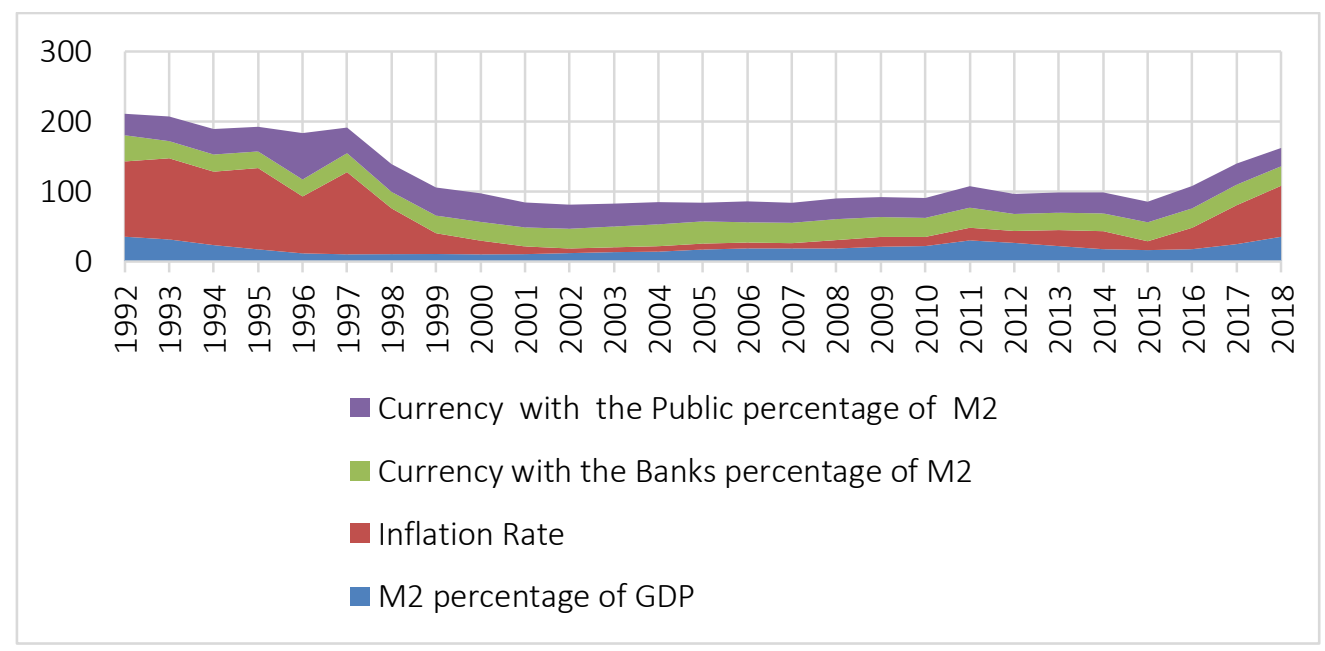

Figure 4. Monetary Policy Indicators 1992-2018

Source: CBOS, Annual Reports (1992-2018)

International Journal of Islamic Economics and Finance (IJIEF), 3(2), 251-282 | 269 
Mustafa Impact of Liquidity Shortage Risk on Financial Performance of Sudanese Islamic Banks

Table 4 and figure 4 display that, the proportion of currency with public to M2 measures the extent of banking awareness and public confidence (people's behavior) in dealing with the banking system. This measure during (1992-2018) ranged between (26.2\%-66.3\%) leading to the liquidity shortage crisis in 2018.

The proportion of currency with ICBs to $\mathrm{M} 2$ is a good indicator to measure ability of banks to attract people to deposit their excess money. This measure during (1992-2018) ranged between (23.5\%-37.4\%) indicating a significant quantity of money outside the banking system.

All through 1990s and 2000s, except (2002-2007) Sudan economy faced a high inflation (more than two digits). In general, a higher inflation reduces the purchasing power of money; to caused people demanded more cash withdraw to meet their basic needs as happened in 2018.

Except 1992,1993 and 2018, the proportion of M2 to GDP ranged between (10.1\%-29.9\%) and it sharply increased from $24.6 \%$ in 2017 to $35 \%$ in 2018 that caused an increase in inflation rate from $55.6 \%$ to $72.9 \%$.

\subsubsection{Reasons of Banks' Liquidity Shortage in Sudan -2018}

Since secession of South Sudan in July 2011, Sudan economy has been exposed to economic crisis resulted in shortage of cash in both local and foreign currencies. As a result of separation, the state lost foreign exchange resources due to losses of oil exports. Oil revenue up to 2011 fed the public budget of the state by $70 \%$ of the total revenues. Furthermore, loss of oil exports revenues led to the erosion of foreign reserves.

At the same time increase of demand for the hard currencies - U.S Dollar led to the deterioration of domestic currency. So in the year 2018 there is a high increase in demand for cash withdrawals from the different types of deposits in order to use dollar as store of value.

Table 5. Some Economic Indicators after Secession of South Sudan (2011-18)

\begin{tabular}{cccc}
\hline Year & $\begin{array}{c}\text { Exchange Rate } \\
\text { SDG/USD }\end{array}$ & $\begin{array}{c}\text { Deficit of the Public } \\
\text { Budget share of GDP }\end{array}$ & $\begin{array}{c}\text { Deficit of Trade } \\
\text { Balance share of } \\
\text { GDP }\end{array}$ \\
\hline 2011 & 2.88 & 5.2 & 1.13 \\
2012 & 4.40 & 3.4 & 1.82 \\
2013 & 5.70 & 2.1 & 1.29 \\
2014 & 6.04 & 0.9 & 0.85 \\
2015 & 7.50 & 1.2 & 0.92 \\
2016 & 15.15 & 1.6 & 0.65 \\
2017 & 21.6 & 1.9 & 0.53 \\
2018 & 46.5 & 3.1 & 0.29 \\
\hline
\end{tabular}

Source: Authors Calculation and CBOS (2018, p.225).

International Journal of Islamic Economics and Finance (IJIEF), 3(2), 251-282 | 270 
Mustafa Impact of Liquidity Shortage Risk on Financial Performance of Sudanese Islamic Banks

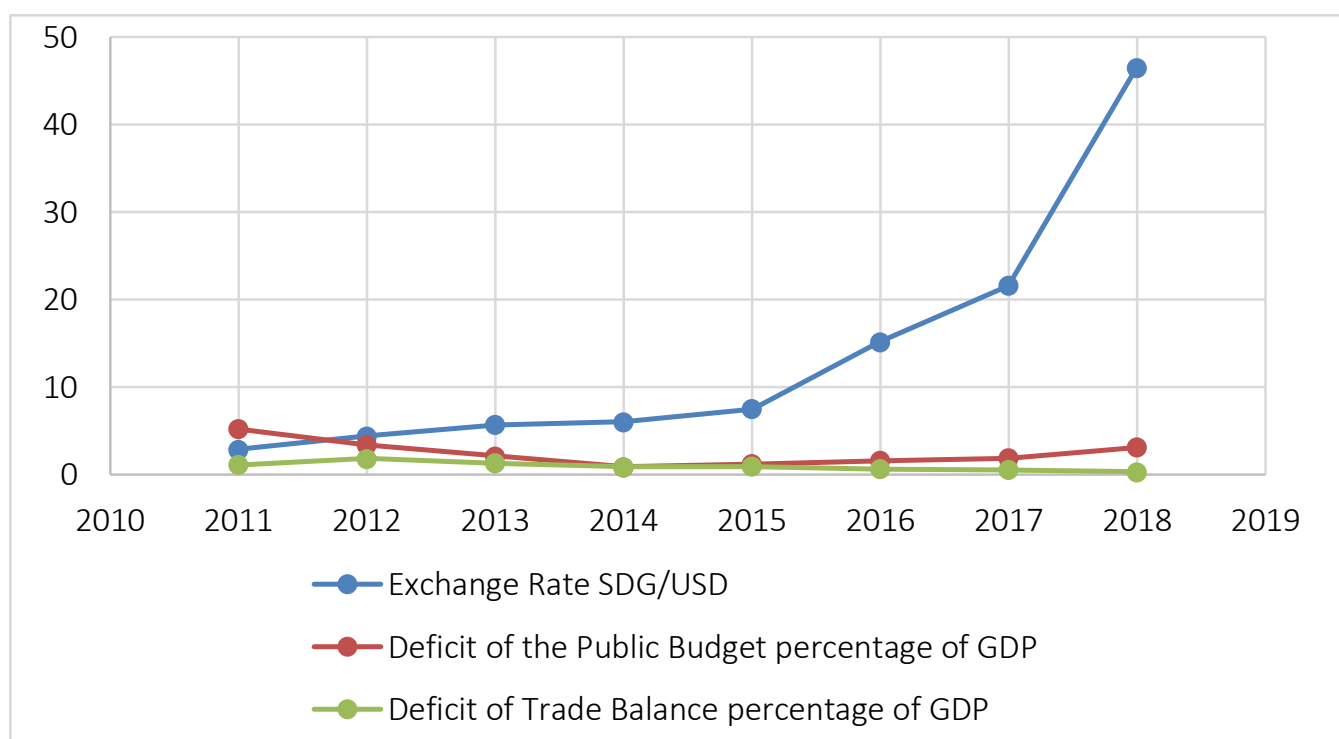

Figure 5. Trend of Economic Indicators after Secession of South Sudan 2011-18

Source: Author's Calculation and (CBOS,2018, p225).

Data in table (5) and displayed by figure (5) shows that South Sudan secession left a negative impact on Sudan economy, moreover, it led to worse the liquidity position of ICBs for the following reasons:

Value deterioration of the local currency against U.S Dollar where the exchange rate increased from SDG2.88 per dollar in 2011 to SDG46.5 per dollar in 2018 motivating people to withdraw their money from their bank's accounts (current, investment or savings) to buy dollar in order to protect the real value of their liquid assets.

The highest deficit of public budget of the state reached 5.1\% of GDP in 2011 at the time of secession. But it gradually reduced to $3.1 \%$ in 2018 consequently the CBOS has expanded the supply of money to $35.1 \%$ in 2018 to finance the deficit. This procedure led to pull up inflation and increase demand for local currency.

Trade balance deficit increased from 1.13\% in 2011 to 1.82 in 2012 as share of GDP as result of reduction of Sudan's oil exports which contribute to shortages of hard currency.

Administrations of ICBs were unsystematic expanding provision of finance focusing on their customer's deposits. It ranged between (54.8\%-85.2\%) of total deposits during 2011-2018.

ICBs determined the maximum limit of cash withdrawal from the bank accounts not to exceed SDG 2000 (equivalent \$43) per day and the situation deteriorated to SDG 300 per day by the end of December 2018. 
Mustafa Impact of Liquidity Shortage Risk on Financial Performance of Sudanese Islamic Banks

ICBs failed to fill ATMs with cash to provide their customers with enough cash, so they failed to meet the demand for money (CBOS,2018).

Loss of customer's confidence in the banking system accelerates withdrawals of cash and refrain from deposits in bank accounts leading to increase of money outside banks (CBOS,2018).

CBOS continued printing and injecting currency into the economy to meet the rush for cash withdrawal (CBOS, 2018, p.39).

Lack of confidence in other methods of payment (electronic transfer of funds from account to another account) hence, a very small proportion of the public uses the sales points and electronic payment.

However, these reasons led to the emergence of LSR in ICBs in Sudan. However, it was accentuated by many other factors beside the drop in oil revenue, such economic resources mismanagement.

\subsection{Results of Multiple Estimation Model}

The results of the estimated parameters using OLS showed in the following table.

As seen in table (6), the results OLS showing that:

The Durbin Watson (DW) statistic shows that regression does not suffers from autocorrelation because the value of DW approximately 2.0 means that the sample free of autocorrelation.

The value of the Regression Standard Error (S.E 1.09: fall within plus/minus 2) indicating that the regression model is on average used the data of the response variable or the observations are closer to the fitted line.

Table 6. Ordinary Least Squares Regression Results

\begin{tabular}{|c|c|c|c|c|}
\hline \multicolumn{5}{|c|}{$\begin{array}{l}\text { Dependent Variable: ROA Method: Least Squares, Date: 03/20/20 } \\
\text { Sample: Included observations: } 27\end{array}$} \\
\hline Variable & Coefficient & Std. Error & t-Statistic & $\begin{array}{l}\text { Probabilit } \\
\text { y }\end{array}$ \\
\hline C & 10.36715 & 5.255208 & 1.972739 & 0.0612 \\
\hline $\mathrm{CD} / \mathrm{TD}$ & -0.088094 & 0.055436 & -1.589119 & 0.1263 \\
\hline INF & -0.020939 & 0.006965 & -3.006146 & 0.0065 \\
\hline LA/TA & 0.075921 & 0.025047 & 3.031133 & 0.0061 \\
\hline TF/TD & -0.005562 & 0.014024 & -0.396618 & 0.6955 \\
\hline R-squared & 0.555279 & \multicolumn{2}{|c|}{ Akaike info criterion } & 3.188538 \\
\hline Adjusted R-squared & 0.474421 & \multicolumn{2}{|c|}{ Schwarz criterion } & 3.428508 \\
\hline S.E. of regression & 1.096960 & \multicolumn{2}{|c|}{ Durbin-Watson stat } & 2.236163 \\
\hline F-statistic & 6.867317 & \multicolumn{2}{|c|}{ Prob(F-statistic) } & 0.000957 \\
\hline
\end{tabular}

Source: Author's Calculation 
Mustafa Impact of Liquidity Shortage Risk on Financial Performance of Sudanese Islamic Banks

The value of Akaike information criterion is 3.1, representing that the optimal model is selected compared to the value of R2 or Adjusted R-Squared.

The value of Schwarz Criterion (3.4) is moderated compared to the value of Akaike information criterion. It helps select the least complex probability model among multiple options.

The value of Adjusted R- Squared is 47, showing that the explanatory powers (LA/TA, CD/TD, TF/TD and INF) are explained about $47 \%$ of total changes in the financial performance (measured by ROA).

The variable of liquid assets to total assets (LA/TA) showed a positive sign (probability of 0.0061 ) representing that a rise of liquid assets will leads to reduce the LSR and would probably improve the performance of ICBs by (0.075921) percent.

The estimated parameter of current deposits to total deposits ratio (CD/TD) has a weak a negative signal in its relations to the performance of ICBS because the probability value is greater than 0.05 (0.1263), representing that an increase of current deposits might lead to improving liquidity position and reducing LSR but it is likely to negatively affect the performance by $(0.08)$ percent.

The estimated factor of total finance to total deposits (TF/TD) appeared with a negative mark and it has probability value of (0.6955) telling that if ICBS expand grant financing based on their customers' deposits would probably lead to improving the profitability but if client fail to pay back the principal investment or the financing, this situation may lead to LSR consequently adversely affecting the performance of ICBs.

The projected parameter of inflation (INF) performed a high a negative influence on the profitability of ICBs because the probability value of inflation is less than (0.05) approximately (0.0065) displaying that the increase of inflation rate by one percent maybe lead to reduction the financial performance by (0.020939) percent. Thus, in inflationary period ICBs prefer to choose not give out financing or credit.

The depreciation of local currency has a negative influence on ROA. So, banks which operating in countries suffering from hyperinflation as happened in Sudan in 2018 where inflation reached $72.9 \%$ therefore banks faced high cash withdrawal from their costumers' accounts. In such situation, LSR will take place exhibiting a lower financial performance of ICBs. 
Mustafa Impact of Liquidity Shortage Risk on Financial Performance of Sudanese Islamic Banks

\subsection{Analysis}

The model mentioned in table (6) aimed to investigate the impact of liquidity shortage risk and inflation on the performance (ROA) of Islamic commercial banks in (1992-2018) period in Sudan.

The intercept or the constant term (C) is significant because it has value $>0$ equivalent to (10.36715) and the probability value of $(C)$ is approximately 0.05 indicating that there is a linearity between the dependent variable and independent variables as assumed in the method/methodology of the research.

All the coefficients' value $(-0.088094,-0.020939,0.075921$ and -0.005562$)$ of the independent variables (CD/TD, INF, LA/TA and TF/TD) respectively, have value $<1$, indicating that the independent variables have influence on ROA.

The independent variables (CD/TD, INF, LA/TA and TF/TD) have Standard Error (0.055436, 0.006965, 0.025047 and 0.014024), t-Statistic (-1.589119, $3.006146,3.031133$ and -0.396618$)$ and probability value of $(0.1263,0.0065$, 0.0061 and 0.6955$)$ respectively. Statistically, when the variable has low value of standard error, high value of t-statistic and probability value $<0.05$, we can judge that the variable is significant. Therefore, except CD/TD, set of independent variables have a significant influence on ROA.

The comparison between Adjusted R-squared (0.474421) and the value of Fstatistic (6.867317) shows that some variables are not included in the model, therefore, explanatory powers (LA/TA, CD/TD, TF/TD and INF) clarified about $47 \%$ of the banks' performance variation. But the overall regression is effective and significant because, the value of $\mathrm{F}$ - statistic is high (6.867317) and it has probability of $(0.000957)$. This results approves the works of Almumani (2013), Moussa (2015), Mustafa (2019b) and Mustafa (2019a) because their methodologies were used the financial data/ratios to measure the liquidity position of banks as was done in this study.

\section{Conclusions and Recommendations}

\subsection{Conclusions}

The study found that the indicators of liquidity shortage risk (LSR) in terms of the ratios of Current Deposits to Total Deposits (CD/TD), Total Finance to Total Deposits(TF/TD) and Inflation (INF) had negative relationships with the financial performance of ICBs measured by Return on Assets (ROA). These results are agreed with the results of Almumani (2013), Moussa (2015) and Mustafa (2019a) that the inflation rate have a significant negative influence on bank's liquidity in Jordan, and Tunisia and Sudan respectively. Whereas 
Mustafa Impact of Liquidity Shortage Risk on Financial Performance of Sudanese Islamic Banks

the ratio of Liquid Assets to Total Assets (LA/TA) had positive relationships with ROA. This agrees with the work of Mustafa (2019b).

For the question why (CD/TD) affect negatively ROA Sudan banks? because the increases of current deposits of private sector (equivalent $85 \%$ of the total current deposits of banks on average as mentioned by the Central Bank in its annual report for the year 2018) improves liquidity position of ICBs and reduces LSR. But trade- between liquidity and profitability will take place. Thus, with higher liquidity ratios, the financial performance of banks with will be declined. This totally agrees with Raina (2013), moreover, the expansion of financing based on customer's deposits (current) exposes banks to LSR.

Despite the high ratio of liquid assets to total assets of 52\% in 2018, ICBs were exposed to LSR due to inability to liquidate assets to meet cash withdrawals. Banking deposits represent $45.7 \%$ of money supply in 2018; this means that there is a huge quantity of money outside the banks system indicating the reduction awareness and confidence of public in banking system or in another word clients' behavior changed.

The Central Bank of Sudan implemented an expansionary monetary policy through increasing the money supply that reached 35\% of GDP in 2018. This action led to increase inflation rate to $72.9 \%$ caused a poorer value of domestic currency. High inflation motivated depositors to withdraw more cash from their bank accounts and buy dollars to protect their liquid assets, which exposed ICBs to LSR. Therefore, the monetary policy was not effective in reducing ICBs' exposure to LSR, especially in 2018 due to the rapid increase in money supply that caused hyperinflation.

The study found that the secession of South Sudan in the year 2011 and the changed of the political system in 2018 (political and economic instability) is the main factor behind this correlated series of negative effects on the Sudan economy in general and the banks particularly through the following transmission channels:

During 1992-2010: Sudan economy and Banking Sector were in stable position.

Since 2011: South Sudan secedes and Sudan loosed oil exports. The Public budget of the state loosed more $75 \%$ of its oil revenues (were the major source of obtaining hard currency).

Beyond 2011: The Public budget of the stated faced a chronic deficit (equivalent 5.2\% of GDP in 2011 and 3.1\% in 2018). Also Sudan's trade balance achieved large deficit (equivalent $1.13 \%$ of GDP in 2011).

The state began to search for a new internal funds resources to cover the deficit such mining gold but external funds not allowable for the state due to American sanction on Sudan economy. 
Mustafa Impact of Liquidity Shortage Risk on Financial Performance of Sudanese Islamic Banks

To meet the deficit, the Central Bank became forced to print more amounts of money than the actual need. The interrelated effects exhibit hyperinflation reached more than $72 \%$ by the end of 2018 .

The public and costumers of the banks lost their confidence in local currency, banking system and the state. A huge cash has been withdrawal from banks accounts in order to converted to dollar (as store of value). In such a position, banks find themselves unable to meet customers 'cash withdrawals, therefore, liquidity shortage risk actually occurred in 2018.

\subsection{Recommendations}

\subsubsection{Recommendations for Central Bank of Sudan (CBOS)}

- Banks in Sudan are operating under high inflationary pressures; therefore, CBOS have to implement contractionary monetary policy to monitor/control inflation by reducing supply of money to appreciate local currency.

- CBOS' methodologies of measuring the supply of money (M1, M2 and M3) may need to update/re-evaluate and includes: new definitions, different measures, instruments to assess, control and monitor.

- To reduce demands for cash, CBOS need to activate of electronic payment systems such force banks to increase the number of ATM, ATMs cards, Point of Sales and E-Purse Cards.

- CBOS should issuance policies aimed at keeping and sustaining financial solvency and stability of the banks to complies with the international standard ratio of capital adequacy, which can be achieved through the activation of banking supervision especially banks' liquidity management.

\subsubsection{Recommendations for Inter-Banks Liquidity Management Fund (IBLMF)}

IBLMF was founded in Aug 2015, with an opening capital of SDG 750.0 million, of which $40 \%$ of the contribution paid in cash and $60 \%$ in marketable government securities. IBLMF started its work in Sept 2016, and increased its capital in October 2016 to reach SDG 900.0 million, because of the contribution of all the working banks in Sudan; with a nominal value SDG 1,000 for the share. IBLMF aims at assisting the banks in managing their short period surplus/shortage liquidity, and encourages the instruments exchange between them, and reaching appropriate return from the fund's investment. The study recommends IBLMF to increase its capital to the level that suits the member banks' assets and liabilities. Moreover, IBLMF should 
Mustafa Impact of Liquidity Shortage Risk on Financial Performance of Sudanese Islamic Banks

activate Islamic financial engineering to develop new financial instruments that help banks to invest their funds in times of excess liquidity.

\subsubsection{Recommendations for Bank Deposit Security Fund (BDSF)}

BDSF was founded in light of its 1996 Act, with a share of capital paid by the CBOS and Ministry of Finance and Economic Planning. BDSF aims at providing Islamic banks with Islamic insurance for their deposits. The study recommends BDSF to extend its aims not only to insurance costumers' deposits in the event of bankruptcy but also to cover the risk resulted from the overall acute shortage of liquidity that Islamic banks may be faced.

\subsubsection{Recommendations for Islamic Commercial Banks (ICBs)}

- To reduce LSR, ICBs should not expand in the provision of finance depending on customers' current deposits because their ability to meet cash withdrawal will reduce. As a result, the performance will deteriorate as well.

- To ensure profitability and improving the financial performance, ICBS need to use prudent LSR management.

- In light of acute shortage of liquidity as happened in 2018, ICBs need more efforts towards completion the guiding principles of BCBS in the context of capital adequacy to support ability of regulatory capital to contend with LSR.

- Diversification of financial assets (with high liquidity) protects ICBS from exposure to LSR.

- In order to support the costumers' confidence on the ICBs, the return on investment accounts and on other financial products (subject to Islamic rule) need to be protected. Because the beneficiaries are compare between return and inflation rate. If inflation is hyper and greater than return, simply depositors will withdraw their deposits quickly and convert them into other stable assets such buying dollar, gold or real-estate. This exactly what happened in 2018 as banks were in a complex dilemma.

- Islamic Banks needs to develop instruments help them to utilization of surplus of liquidity. Moreover, acquire return helping in period of liquidity shortage and reduces the dependency on the Central Banks as lender of last resort.

\subsubsection{Recommendations for Further Research}

In light of the importance of liquidity risks management in general and the risks of liquidity shortage in particular, the study suggested conducting further research in the following areas: 
Mustafa Impact of Liquidity Shortage Risk on Financial Performance of Sudanese Islamic Banks

- Updating the methodologies of measuring costumers' behaviour and confidence on Islamic banks regarding to liquidity shortage risk.

- How Islamic Central Banks act as lender of last resort in light of prohibition of interest rate.

- Efficiency of Inter- Islamic Banks Liquidity Management Funds.

- Assessment the Efficiency of Inter- Islamic Banks Market.

\section{Acknowledgements}

The author would like to thank Mr. Othman Al-Khader Mustafa (Economist), Dr. Ishraqa Khatab (Director of research Centre: Sudan Academy for Banking and Financial Sciences) and Dr. Mustafa Mohammed Musnad (Head Department of Banking and Financial Studies: Sudan Academy for Banking and Financial Sciences) for their helpful comments and proofreading. 
Mustafa Impact of Liquidity Shortage Risk on Financial Performance of Sudanese Islamic Banks

\section{References}

Adam, M. H. (2014). Evaluating the financial performance of banks using financial ratios: A case study of erbil bank for investment and finance. European Journal of Accounting Auditing and Finance Research, 2(2), 156-170.

Almani, M. \& Oehler, A. (2012). Liquidity transformation factors of Islamic banks: An Empirical Analysis. Retrieved April 4,2020, from https://www.mfsociety.org/modules/modDashboard/uploadFiles/co nferences/MC19 343 p16jh8l10rojpths1pem1lso170h4.pdf.

Almumani, M. (2013). Liquidity risks management: A comparative study between Saudi Arabia and Jordanian Bank. Interdisciplinary Journal of Research in Business, 3(2), 1-10.

Ariffin, N. (2012). Liquidity risk management and financial performance in Malaysia: Empirical evidence from Islamic banks. Aceh International Journal of Social Sciences, 1(2), 77-84.

Basel Committee on Banking Supervision. (2008). Liquidity risk management and supervisory challenges. Switzerland: BIS. Retrieved April 3,2020, from https://www.bis.org/publ/bcbs136.pdf.

Berríos, M. (2013). The relationship between bank credit risk and profitability and liquidity. The International Journal of Business and Finance Research, 7(3),105-118.

Bessis, J. (2009). Risk management in banking. New York John: Wiley \& Sons.

Bank for International Settlement. (2000). Sound practices for managing liquidity in banking organizations. BIS. Retrieved March 29,2020, from https://www.bis.org/publ/bcbsc135.pdf

Central Bank of Sudan. (2018). Annual Reports. Khartoum: CBOS. Retrieved May 7,2019, from http://www.cbos.gov.sd

Cucinelli, D. (2013). The determinants of bank liquidity risk within the context of euro area. Interdisciplinary Journal of Research in Business, 2(10), 51-64.

Diamond, D., \& Rajan, R. (2005). Liquidity shortages and banking crises. Journal of Finance,60(2), 615-647.

European Central Bank. (2018). Task Force on Systemic Liquidity: Systemic Liquidity Concept, Measurement and Macro-Prudential Instruments, ECB Occasional Paper, No. 214, ISBN 978-92-899-3373-5, Frankfurt a. $\mathrm{M}$.

Fox, J. (2016). Applied regression analysis and generalized linear models. Thousand Oaks, California: Sage Publications. Retrieved July 14, 2020, from https://us.sagepub.com/en-us/nam/applied-regressionanalysis-and-generalized-linear-models/book237254

Greuning, V., \& Iqbal, H. (2008). Risk analysis for Islamic banks. Washington, D. C: World Bank. 
Mustafa Impact of Liquidity Shortage Risk on Financial Performance of Sudanese Islamic Banks

Hidayat, S., Khalifa, M., \& Aryasantana, A. (2012). A survey on the level of effectiveness of liquidity risk management of Islamic banks in Bahrain. International Journal of Finance and Economics, 1(91),14502887.

Hull, J. (2012). Risk management and financial institutions. New York: Wiley \& Sons

Islamic Financial Services Board. (2013). Credit Risk Management in Islamic Banks. Malaysia: IFSB \& INCEIF. Retrieved April 3,2020, from http://www.ifsb.org.

Islamic Financial Services Board. (2012). Guiding Principles on Liquidity Risk Management for Institutions Offering Islamic Financial Services. Malaysia: IFSB. Retrieved April 3,2020, from http://www.ifsb.org.

Jaara, O., Jaara, B., Shamieh, J., Fendi, U. (2017). Liquidity risk exposure in Islamic and Conventional banks. International Journal of Economics and Financial Issues, 7(6),16-26.

Khartoum Electronic Media Centre. (2018). Liquidity Shortage in Sudanese Banks. Retrieved May 7,2019,from https://www.khartoumcenter.com/new/s/58248.

Kumari, K., \& Yadav, S. (2018). Linear regression analysis study. Journal of the Practice of Cardiovascular Cardiovasc Sciences, 4(1),33-36.

Mahaboob, B., Venkateswarlu, B., Narayana, C., Ravi, C., Balasiddamuni, P. (2018). A Treatise on ordinary least squares estimation of parameters of linear model. International Journal of Engineering \& Technology, 7 (4.10), 518-522.

Marianne. (2001). The effect of macroeconomic conditions on bank, risk and profitability (Working Paper Series WP2001-06). Australia: Reserve Bank of Australia.

Mazur, A., \& Szajt, M. (2015). Determinants of liquidity risk in commercial banks in the European Union. Argumenta Oeconomica, 2(35), 25-46.

Mekasha, G. (2011). Credit risk management and Its impact on performance on Ethiopian commercial banks (Master Thesis). Addis Ababa University.

Mosteller, Frederick, \& Tukey, W. (1977). Data Analysis and Regression. Reading, MA: Addison-Wesley.

Mounira, B., \& Anas, A. (2008). Managing risks and liquidity in an Interest free banking framework: The case of the Islamic banks. International Journal of Business and Management,3(9),80-95.

Moussa, M. (2015). The determinants of bank liquidity: Case of Tunisia. International Journal of Economics and Financial Issues, 5(1), 249259.

Mustafa, O. A. (2019a). Assessment of the financial performance of Islamic commercial banks in Sudan under credit risk and inflation pressures (1995-2017). Journal of Islamic Banking and Finance, 7(1),14-26. 
Mustafa Impact of Liquidity Shortage Risk on Financial Performance of Sudanese Islamic Banks

Mustafa, O. A. (2019b). The conflict between liquidity and profitability and its impact on the banking finance: An empirical investigation from Sudan (2000-2018). Global Academic Journal of Economics and Business,1(1),27-32.

Mustafa, O. A. (2020). Why do Islamic banks concentrating finance in Murabaha mode? Performance and risk analysis (Sudan: 1997-2018). International Business Research,13(7),208-223.

Peprah, M., \& Mensah, O. (2017). Performance evaluation of the ordinary least square (OLS) and total least square (TLS) in adjusting field Data: An empirical study on a DGPS Data. South African Journal of Geomatics, 6(1),73-89.

Rania, A. (2013). Risk management for Islamic banks. Edinburgh: University Press.

Resti, A., \& Sironi, A. (2007). Understanding and measuring liquidity risk, Bancaria, 63(11), 2-17.

Scannella, E. (2016). Theory and regulation of liquidity risk management in banking. International Journal of Risk Assessment and Management, 19(1/2), 4-21.

Shen, C., Chen, Y., \& Kao, L. (2009). Bank liquidity risk and performance. Retrieved March 3, 2020, from https://www.researchgate.net/publication/228366383

Sinkey, J. F. (1992). Commercial bank financial management: In the financialservices industry. New York: MacMillan.

Tutino, F. (2012). Liquidity management in the bank. Bologna: II Mulino.

Yaacob, S., Abdul, R. A., \& Abdul, K. Z. (2016). The determinants of liquidity risk: A panel study of Islamic banks in Malaysia. Journal of Contemporary Issues and Thought, 6(1), 73-82. 
Mustafa Impact of Liquidity Shortage Risk on Financial Performance of Sudanese Islamic Banks

This page is intentionally left blank

International Journal of Islamic Economics and Finance (IJIEF), 3(2), 251-282 | 282 